\title{
Nations spar over erosion of nuclear treaty
}

Geoff Brumfiel

The world's largest treaty to stop the spread of nuclear weapons is broken, but nobody can agree on how to fix it.

Representatives from more than 180 nations are meeting in New York over 2-27 May to discuss the Nuclear Non-Proliferation Treaty. But as Naturewent to press in the meeting's second week, the atmosphere was bad tempered and participants had yet to agree an agenda.

The treaty requires nations with nuclear weapons to work towards disarmament, and those without to remain free of nuclear weapons in return for access to nuclearpower technology. Member states hold a meeting to review it once every five years.

Since it came into force in 1970, the treaty has been a bulwark against the proliferation of nuclear technologies. But in recent years, its authority has been increasingly challenged, and relations between member states have worsened. Activist groups have warned that agreeing a way forward at this month's meeting is essential if trust in the treaty is not to be eroded irreversibly (see Nature 433, $184 ; 2005)$.

Mohamed ElBaradei, director of the International Atomic Energy Agency, which polices the treaty, made the same warning to delegates when the conference opened. Without modification, he said, the treaty "will fade into irrelevance and leave us vulnerable and unprotected".

Challenges to the treaty are coming from all sides (see'Problem States'below). In 1998, India and Pakistan, who have not signed the treaty, tested nuclear devices. In 2003, North Korea announced its withdrawal from the treaty to pursue a nuclear weapons programme.Member states were left scrambling to work out how to respond, and lawyers are still arguing over whether North Korea's withdrawal was valid, as it was being investigated for suspicious activities when it decided to pull out.

Meanwhile, treaty members such as Brazil and Iran have been developing uranium-enrichment technologies that could allow them to produce abomb in short order. In the case of Iran, many experts now agree that the goal of the programme probably is a weapon, not nuclear power as the country claims (see Nature 432, 432; 2004).

What's more, the benefits offered to nonweapons states for being part of the treaty are beginning to erode. Nuclear technology is now available on the black market, largely thanks to Abdul Qadeer Khan, the father of Pakistan's nuclear bomb. Last year Khan confessed to having headed an extensive network of scientists, engineers and businessmen who were selling nuclear secrets.

In addition, a rift is opening between

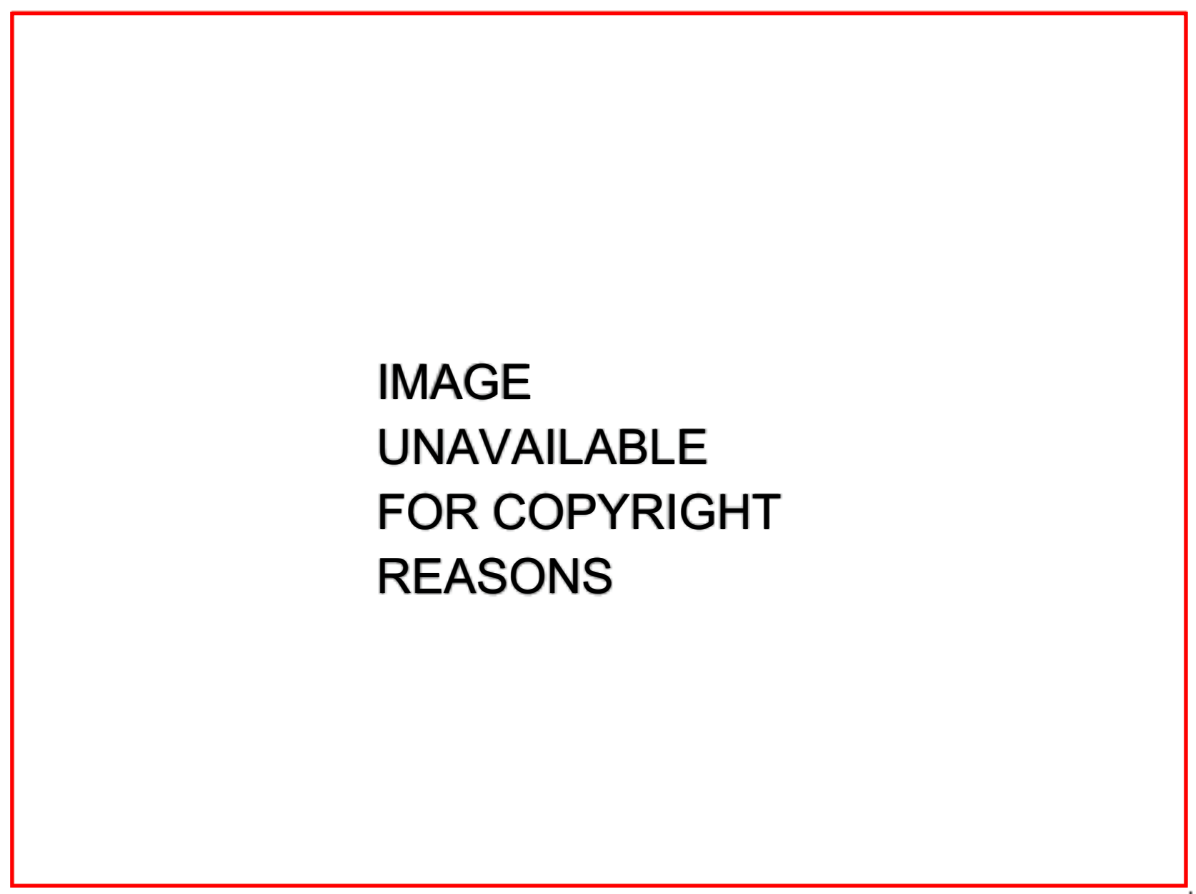

Mohamed EBBaradei warns an international meeting that its nuclear treaty may 'fade into irrelevance'.

non-weapons states and the nuclear powers. Many of the former say that the five nuclear states - the United States, Britain, France, Russia and China - are failing to honour their obligations to disarm. Although these five nations have reduced the number of weapons in their stockpiles, critics point to their continued emphasis on the value of nuclear weapons as a deterrent. The United States in particular is developing new weapons, such as missile defence systems that could instigate a new arms race in space, and ground-penetrating 'bunker busters'.

Most parties are agreed at least on which parts of the treaty need to be strengthened. Inspectors must be given the power to search more nuclear facilities and to conduct shortnotice inspections. Withdrawal from the treaty, which at present simply requires a three-month notice period, should be made more difficult. And many delegates want the weapons states to reaffirm their commitment to disarmament.

"There's a remarkable convergence about what the problemsare," says Rebecca Johnson, director of the London-based Acronym Institute for Disarmament Diplomacy, who is sitting in on the conference. "But there's very little agreement over how to deal with them."

Delegates spent the first week of the meeting offering a bewildering range of opinions on what should be done. The US delegation wants to withhold enrichment technology, which is used to purify uranium fuel but also to make weapons-grade uranium, from countries such as Iran that have

\section{Problem states}

The Nuclear Non-Proliferation Treaty has 187 signatories, but only a handful of these nations present real challenges to the treaty's future.

The 'big five' Under the treaty, the United States, Britain, China, Russia and France must all "pursue negotiations in good faith" towards disarmament. They say they are living up to their obligations, but other states say they must do more to limit their nuclear arsenals.

The wheelers and dealers Japan, the Netherlands, France, Russia and Germary all profit from the sale of nuclear technology abroad, and are loath to restrict where they peddle their wares. Their clients, such as Brazil and Iran, are equally set against new limits.
The outsiders Israel, Pakistan and India have developed nuclear weapons (pictured right), but are not signatories. Many of their neighbours signed the treaty in the hope that their regions would be nuclear-free - that hasn't happened.

North Korea It withdrew from the treaty in 2003 , and may now be planning tests. Most experts agree that it was allowed to pull out too easily; many want to make withdrawal harder.

Iran The country is developing an advanced uranium-enrichment programme that until recently remained hidden from inspectors. It claims it is upholding its right to pursue the "use of nuclear energy for peaceful purposes" under the treaty. Others say its programme is a front for a bomb. 
obstructed nuclearinspectors. Other suggestions included a moratorium on uranium enrichment, or allowing it only at plants under international control.

South Korea argued that withdrawal from the treaty should become contingent on approval by the United Nations Security Council, a rule that would have prevented North Korea from pulling out. And a host of countries, including Brazil and Egypt, called for substantial reductions in the nuclear arsenals of the five weapons states.

But each proposal raises its own issues among the other delegates. The United States is likely to resist any effort to curtail its nuclear arsenal. And placing restrictions on nuclear technologyin certain states will meet resistance from members such as France and Germany, which profit from sales abroad.

The situation is so difficult that most observers doubt much will come of the conference. The treaty is unlikely to be amended for fear that the entire document may fall apart, says Michael Levio of the Brookings Institution, a non-partisan think-tank in Washington.

A more likely outcome could be a 'consensus document' on how to reinterpret the treaty. Such documents, which require the unanimous approval of all member states, have been created twice before: once in 1995 and again in 2000 , in which a 13-step plan towards disarmament was proposed. A new one to strengthen the role of inspectors might stand a chance of success. Still, as Levi points out, "Iran would have to agree to it", which is unlikely. Other members might try to argue that the inspections of weapons states, which are currently voluntary, should be strengthened as well, but the 'big five' would be unlikely to approve.

Johnson is still hopeful that agreement will be reached, but says it won't beeasy given the acrimonious tone of the conference. She calls on nations to make compromises - or risk nuclear weapons technology spreading out of control. ${ }^{\alpha}$ Quite a lot of states are protecting their own interests over and above international security," she fears.

\section{IMAGE}

UNAVAILABLE FOR COPYRIGHT REASONS
IMAGE UNAVAILABLE FOR COPYRIGHT REASONS

Waiting in line: Indonesia stepped up vaccinations after a Nigerian poliovirus paralysed four children.

\section{Polio fight falters as Yemen and Java report fresh cases}

\section{Carina Dennis, Sydney}

Polio is spreading to countries previously considered free of the disease, following a vaccine boycott in Nigeria in 2003. An outbreak in Yemen has sparked fears of an epidemic in the poorly immunized Middle Eastern nation. And the virus has now reached southeast Asia, with four cases confirmed in Indonesia last week.

Polio has not been seen in Yemen and Indonesia for a decade. Genetic analysis shows that the virus appearing in both areas is similar to the one that caused a 2003 outbreak in Nigeria. Polio vaccines were rejected in northern Nigerian states after Muslim clerics claimed they had been contaminated with HIV and contraceptives. Sixteen 'polio-free' countries have reported cases since 2003.

"The recent outbreaks can be traced back to that boycott," says Arun Thapa, an adviser on polio eradication in southeast Asia for the World Health Organization (WHO), based in New Delhi.

In April, the WHO confirmed 22 cases in Yemen, and health officials anticipate further infections because of low immunization rates among the nation's children. "We expect there will be many times this number," says Mohamed Wahdan, the WHO's Eastern Mediterranean polio adviser.

Middle Eastern nations have been on high alert for polio since December 2004 and many have already started preventative vaccination programmes. "Unfortunately, the virus spread ahead of the campaign in Yemen," says Wahdan. "We hope to be ahead of the virus in other regions."

This month, Yemen will initiate a houseto-house campaign to vaccinate all its $3 \mathrm{mil}-$ lion children under 5 years of age. Health officials are using a polio vaccine specifically targeted at the virus responsible for the outbreak, which theysay provides greaterimmunity with fewer doses. "We believe it is the best tool in the face of an epidemic,"says Wahdan.

In Indonesia, health officials are confident the virus can be restricted to the small villages in West Java where the four cases were reported. "The immunization level in Indonesia has been good, with $95 \%$ coverage of children," says Bardan Rana, the WHO's immunization officer in the country. But officials are taking no chances and are giving supplementary immunization to 5.2 million children under the age of five in West Java and surrounding provinces.

Although the recent outbreaks do not bode well for the eradication of polio, Thapa says he is more concerned about the situation in India. "It is the largest polio-endemic country and has been a source of wild poliovirus for other countries in the past. ${ }^{\text {n }}$

Officials suspect the virus travelled to southeast Asia through Saudi Arabia, a popular destination for Indonesian workers and Muslim pilgrims. "As long as there is polio is in the world and a lot of travel, we expect the virus to beimported,"says Rana. 